\title{
IMPERIAL EXPANSION OF M. E. CHURCH
}

\author{
By The Rev. R. E. HaRvey
}

$$
\text { IV - 1864-1872 }
$$

Had the Rev. U. P. Golliday been on the Iowa Conference side of the boundary in 1864, it would be an interesting speculation as to how he would have characterized the parliamentary tactics of the Reverends Sanford Haines and David N. Smith, delegates from Western Iowa in the General Conference of May 1864, in seeking redress of the wrongs visited upon them in 1860 . For, allied with the Upper Iowa delegation, who cherished some boundary grievances of their own against their common mother Conference, they secured the straightening of that eastern dividing line and took over the west half of Upper Iowa territory.

To the new unit was given the name of their preference-_Des Moines Annual Conference," the eastern line of which starting at the southeast corner of Wayne county ran directly north to the south line of Marshall county, and there connected with a line extending from the southeast corner of Story county north to the Minnesota line, taking in the western half of Iowa and all the Dakotas.13 A region larger than any European empire of that day outside of Russia, and certainly must have looked like a Benjamin's mess in extent ${ }^{14}$ to the group who sat down before it at Clarinda, Aug. 31, 1864. Nor did their new acquisitions consist of acreage alone. Des Moines District received six fine parishes at its northeastern corner, while from Upper Iowa came two entire districts, Fort Dodge having twelve pastoral charges, and Sioux City with five. 1,469 church members came with the real estate, but only three church buildings and six parsonages were re-

\footnotetext{
13See M. E. Church Discipline for 1864, Part VI, Chap. IV, Paragraphs 10, 21. and 53. Dakota does not appear in this connection, but it was included in Upper Iowa limits in its minutes of 1863 , as part of Sioux City District, and was so administered by Des Moines Conference from 1864 onward.

14See Genesis, Chap, 43, Verse 34.
} 
ported for the two districts. "Day of small things" indeed, but not to be despised for out of those small beginnings grew four great Conferences.

Having sketched in some detail the Methodist beginnings in the southern portion of the Des Moines Conference, it is proper that some account be given of operations farther north, since a new division took place only eight years later.

The Boone county pioneer preachers, as previously intimated, accompanied advancing settlement up the Des Moines river, and in 1852 the Rev. H. J. Burleigh held a three days meeting in the hospital tent at Fort Dodge, while that post was a building. ${ }^{15}$ About the same time the Rev. Montgomery, preacher-magistrate at Boonesboro, formed a class in Webster county at the home of Wm. Pierce, from which sprang the Homer M. E. church; and another in Wahkonsa township, as part of his circuit running from Saylorville to Boone river and perhaps further. ${ }^{16}$ With the establishment of regular preaching in Fort Dodge by the Rev. E. R. Clegg in 1854, Webster Mission was set off from Boonesboro Circuit, Presiding Elder Wm. Simpson holding the first quarterly meeting at Homer Dec. 25 of that year. But three classes were reported in the county at that date, Fort Dodge not appearing until March, 1855, with fifty cents contributed for ministerial support. ${ }^{17}$

Growing rapidly Fort Dodge was able to erect a frame meeting house in $1857,{ }^{18}$ and the same year a Swedish M. E. church was formed at Dayton by the Rev. Andrew Erickson, followed the next year by an American society organized by the Rev. W. H. or H. S. Lawton, which group set immediately about church building, incited thereto by Hon. Stephan B. Ayres, leading contributor and di-

${ }^{15}$ History of Fort Dodge and Webster County, by H. M. Pratt, Vol. I, Chap. 4, p. 181.

${ }^{16}$ Centennial History of Webster County, 1876, by E. G. Morgan. The Rev. Montgomery was living in Boonesboro when this work was published, and very likely assisted in preparing the above data.

${ }^{17}$ Illustrated Fort Dodge, p. 154.

${ }^{18}$ Centennial History of Webster County, 1876, by E. G. Morgan. 
rector of construction. ${ }^{19}$ Vesper, also in Sumner township, was occupied that year, with which extension of operations Webster Mission became Webster Circuit in 1855, Fort Dodge Circuit in 1859, and Fort Dodge Station in $1864 .{ }^{20}$ Some forgotten one of these far-ranging scouts must have reached Algona, whose Methodist beginnings are traced to the early 1850's, but whose records begin November 6,1857, with revival services conducted by the Rev. Mr. Lawton, of Fort Dodge Circuit, in the McHugh tavern; the converts of which were most probably formed into a class at that time. He also opened work at Dakota City that same year $;^{21}$ so we see that in about ten years from its founding the old Fort Des Moines Mission and its offshoots had occupied the land clear to the Minnesota line.

\section{North Central Iowa REACHED}

The portion of Des Moines Conference lying east of this picket line was entered mainly from farther east, for a complete account of which the reader is referred to the Rev. Stephen N. Fellows History of Upper Iowa Conference. Methodism entered Hardin county with the Rev. Ethan C. Crippen, local preacher from Canada-“A plain God-fearing man, very zealous, who always went where duty pointed the way," who began work in Hardin and Pleasant townships in 1853; at Eldora and Iowa Falls in 1854 ; next year he preached the first sermon in Etna township, and performed the first marriage ceremony, both at the home of David Hawks. Succeeding years found him laboring with circuit pastors who attached his societies to charges headed by Eldora, Steamboat Rock, Iowa Falls, Ackley and Alden, as these places came upon the map. ${ }^{22}$

\footnotetext{
${ }^{10}$ History of Fort Dodge and Webster County.

20 Ibid.

${ }^{21}$ History of Kossuth and Humboldt Counties, Union Pub. Co., 1881, p. 747.

${ }^{22}$ History of Hardin County, by Historical Department of Iowa, 1883.
} 
Difterent is the story of Hamilton county, ${ }^{23}$ for there, "without benefit of clergy," the first settlers held prayer meetings in each others cabins from 1850 until April of 1854, when the pastor of Webster Mission extended his circuit into Hamilton; the next year the Rev. Andrew Ericson opened Swedish work in the county; in 1857 a class was formed at White Fox schoolhouse by the Rev. David F. Gray, an aged local preacher. After his demise it was served by the Reverends Abbott and Montgomery until 1862 when it was moved into Webster City by the Rev. Wm. Black, where the Methodists shared the city hall with other denominations until able to erect their own house of worship in $1866 .^{24}$

The first religious services in Hancock county were held in the home of Benoni Haskins in the spring of 1858, by the Rev. Mr. McNutt. Some time later, J. W. Elder of Garner prevailed on the pastor at Forest City to hold occasional services at his house, paying $\$ 5.00$ for each trip. Regular work in that place began in 1871, and the Rev. W. W. Robinson organized the Garner M. E. Church in $1872 .{ }^{25}$

The Methodist interpretation of the gospel message was carried into Winnebago county in 1857 by a preacher named Hankins, who, having been a rather undesirable citizen prior to conversion, out of personal knowledge scourged the sins-and sinners-of the community in terms so explicit as to provoke retaliation in a series of pranks, culminating in stealing the wheel caps from his buggy, damaging the vehicle badly and giving the preacher a severe fall, rousing the old Adam in him to the point of promising the culprits a genuine "Peter Cartwright licking," couched in language smacking more of his past vocabulary than suited a minister. Whether Bro. Hankins ever was able to redeem his promise, historians have not

${ }_{29}^{2}$ History of Hamilton County, by J. N. Lee, 1912, Chap. III.

2Albid, Chap. 26, p. 290 ; and p. 324, where the Stratford church is said to have stemmed from a class at Hook's Point.

${ }^{2}$ History of Hancock County, Union Pub. Co., 1883. 
recorded. The Forest City church was organized in 1858, but the Norwegian Methodists provided themselves with a house of worship long before the American society was able to do so. ${ }^{26}$

Northwood church, Worth county, was founded in 1862 by the Rev. Mr. Garner. In Cerro Gordo county the Rev. Mr. Holbrook preached in Portland township in 1856, but other details are lacking until the establishing of churches in Rock Falls and Mason City in 1865, followed by another at Rockwell in 1869 by the Rev. W. S. Dorwin. The first services at Clear Lake were held by the Rev. Elias Pattee, at the residence of Joseph Hewitt, near the lake shore, date not given; but a class was formed at this first meeting, and in November, 1870, the Rev. J. W. Todd, of Fort Dodge District held the first Clear Lake quarterly meeting, James Williams being pastor. ${ }^{27}$

The earliest Methodist work in Franklin county dates to 1853 when the Rev. Mr. Connell of Ackley Circuit began preaching in Osceola township; Oakland church was organized in 1860, by the Rev. Mr. Jones of Alden Circuit; Hampton church was part of a circuit consisting of Shobe's Grove, Chapin and Maysville, until with the erection of a $\$ 6,000.00$ church building, that place was made a station. ${ }^{28}$

Wright county's first sermon was delivered by the Rev. David F. Day in June, 1858, and a class enrolled, consisting of three married couples, which met in a log school house located on the site where in 1889 the Goldfield M. E. church was built. Belmond church was organized in 1860, John Connell first pastor. Dows church then called Otisville organized in 1871 by the Rev. Mr. Hamilton as part of Alden Circuit; Eagle Grove was served from Goldfield until the construction of the railroad; later Wright county Methodist history belongs to the era subsequent to its connection with Des Moines Conference. ${ }^{29}$

${ }^{20}$ Hiatory of Winnebago County. Union Pub. Co., 1883, pp. 742, 747, 887.

2H History of Worth and Cerro Gordo Counties, Union Pub. Co., 1883, pp. 785, 929.

${ }^{2}$ History of Franklin County, Union Pub. Co:, pp. 428 and 499.

${ }^{2}$ History of Wright County, by Hon. B. P. Birdsall, Chap. 15, p. 171. 


\section{The Iowa Lake District}

West of the Des Moines river belt of circuits, the Iowa lake country furnishes a story almost exactly duplicating the rise and fall of Columbus Seminary, previously recorded in these chronicles. Into that romantic region, with a wave of settlers in the late 1850 's came one, the Rev. J. S. Prescott, a preacher who rivalled the contemporary bishops of the church in eloquence. Also he was gifted with the visions of an empire builder, without the practical genius to make them realities; for, conceiving the ambition to found a great university amid those scenes of beauty, he obtained what he was assured were valid options on vast tracts of water front lands, the proceeds of which as residence and farm sites were to erect and endow the institution. Thus equipped, his glowing oratory easily persuaded Upper Iowa Conference to lend the project its approval, and in promotion thereof to create Spirit Lake Mission, covering the four counties of Dickinson, Emmet, O'Brien, and Clay, with the Rev. Cornelius McLean, as Missionary. The mission took root and flourished, was divided, subdivided and parcelled into smaller areas as population increased, but "alas for the preacher's cherished schemes," none questioned for a moment Mr. Prescott's integrity, but his utter ignorance of correct forms of real estate transfers, and utter incapacity to fathom the wiles of land speculators, sunk in vexatious litigation a project that might have made those lake shores a majestic seat of sacred learning. ${ }^{30}$

We have noted formerly that William Black, pioneer missionary at Sioux City extended his travels into Sac county; his advent there was regarded by Mrs. Isabelle Corey, an early settler, as a direct answer to her prayer, offered while kneeling upon the spot long years ago occupied by the Sac City Methodist church, that God would send His Gospel and plant a church in that place.

${ }^{30}$ History of Dickinson County, 1902, by R. A. Smith. 
A class enrolled at the first service met in the Corey home until, in 1857, the first schoolhouse was built; in it the society worshipped for almost twenty years before able to erect a sanctuary. If there were other Methodist churches in the county while attached to Des Moines Conference, we have no record of them. ${ }^{31}$

The Rev. Mr. Black also traversed Ida county the same year-1855-establishing regular preaching in the Moorhead home, ${ }^{32}$ where it continued for sixteen years. The settlers were few and scattered, numbering only 63 in 1865. Ida Grove M. E. church, having ten charter members, and Battle Creek with probably fewer, were organized in 1869 as part of Mapleton Mission, by the pastor, eighteen year old L. H. Woodworth, a tall lanky Kentuckian, son by her first marriage of Mrs Artemis Brown. This earnest youth went to northwest Iowa on invitation of the Rev. Bennett Mitchell, when the latter took charge of Sioux City District, and spent most of his life in that region. He served Ida Grove church four separate terms, totalling twelve years, one-third of the time elapsing between the beginning of his first and end of his last pastorate at that place; probably an unparalleled record anywhere at that era in Methodist administration.

No definite date has been found for Methodist beginnings in Calhoun county, but services were held from 1856 onward at Lake City; one of the earliest pastors was the Rev. Mr. Cadwell, of whom we have no further information; a Sunday school was started by Manson Methodists in 1866, with Robert Glover as superintendent, in the fall of that year the Rev. Mr. King from North Lizard river formed a class at Manson, but we have no further account of Calhoun M. E. churches during the Des Moines Conference jurisdiction. ${ }^{33}$

\footnotetext{
31History of Sac County, 1914, by Wm. H. Hart.

3aInventory of County Records, by W. P. A. Survey, 1938; Historical Collection of Ida County, by Dr. G. E. Moorhead, first born white male child, p. 6 ; ANNALs, April, 1944, p. 311. Dr. Moorhead passed away late in 1944. History N.W. Iowa Conference, p. 346; and elsewhere for L. H. Woodworth.

${ }^{3}$ Past and Present of Calhoun County, by Beaumont E. Stonebreaker, Chap. 15 : Church History. 1915.
} 
Buena Vista county cast only fifteen votes at its organization in 1858, yet with a population of merely fiftyseven in 1860, the church was shepherding them through a class formed the preceding year at Sioux Rapids, by the Rev. O. S. Wright from Cherokee, who delivered the first sermon in the county at the home of Luther Barnes. The Storm Lake church was enrolled October 4, 1868, on the Chamberlain farm at the west end of the lake, by the Rev. Thomas Whitely, a local preacher who supplied a circuit reaching south to Ida Grove, west to Cherokee and north to Peterson; assisted by another local brother named White. They were succeeded in 1870 , by the Rev. J. R. Horswell, who appointed to Storm Lake Circuit, moved the meeting place of the society into the village, preaching the first sermon there in the C. \& N. W. freight depot; yet so scanty was the population in 1872 that the pastor at Sioux Rapids, the Rev. Rufus Fancher included points in Clay county to eke out a living salary. ${ }^{34}$

\section{The NoRThWest Counties}

The first settler in O'Brien county, Hannibal $\mathrm{H}$. Waterman, was a fervent Methodist exhorter, (licensed worker ranking between class leader and local preacher, authorized to hold meetings anywhere he could get hearers; many of whom graduating into the regular clergy) and secured stated services at the earliest date possible, 1858, when the Rev. John Becknell preached the first sermon at Old O'Brien. That fall, Little Sioux Mission was established, extending from Spirit Lake to Cherokee, C. S. Wright, pastor, whose compensation was $\$ 40.00$ mission stipend, and $\$ 27.00$ from his congregations. In 1864 the O'Brien work was placed in Smithland Circuit, and Seymour Snyder armed with bible, hymn book and rifle, equally expert with all three weapons, reached up into Minnesota, travelling seven counties in the' two states. ${ }^{34}$ Past and Present of Buena Vista County, by C. H. Wegerdent and Th. Wal-
pole, 1909 . 
The first house of worship in the county was a sod structure, erected in 1871. In 1914 when the work from which was gleaned the foregoing information was published, O'Brien county boasted a Methodist church in every township; and undoubtedly a number of other denominations also. ${ }^{35}$

The first preaching in Osceola county-date not givenwas by the Rev. S. Aldrich in the home of Elbridge Norman, about one and a half miles west of Sibley; sometime subsequently the Rev. Ira Brasheers, a one armed Civil war veteran, traversed a circuit covering portions of O'Brien, Osceola, Sioux and Lyon counties, while the Rev. John Webb, of Spirit Lake Circuit divided time with Sibley. In April, 1872, Reverends Webb and Aldrich formed a class of nineteen members at the home of $A$. M. Culver, close to Sibley, and the N. W. Iowa Conference at its first session that fall, appointed Webb to Sibley, limiting his field to Osceola county. ${ }^{35}$

Our records of Monona county beginnings are very scanty; certain it is that the itinerants who carried the gospel from Magnolia north to Woodbury, would not bypass the intervening spaces. In 1864 when Onawa Circuit made its first report to Des Moines Conference, by J. M. Hedges, pastor, there were twenty-six members who contributed $\$ 39.50$ for benevolences, and $\$ 404.40$ for pastor and presiding elder. In succeeding years the circuit was served by the Reverends H. H. O'Neal, M. D. Collins, James Lisle, W. E. Hamilton, covering the period until Bennett Mitchell took the Rev. J. M. Rust along with him to supply the Onawa charge; during which period the only recorded advance was represented by a parsonage worth $\$ 300.00$, located ten miles across dreary prairies from town. Not until 1870 did the society in Onawa take organic shape, and until separated from Des Moines Conference was grouped with Woodbury charge. and the statistics grouped likewise. The foregoing items are gleaned mainly from Des Moines Conference Journals. The only

\footnotetext{
s5Past and Present of O'Brien and Osceola Counties, by Hon. Wm. J. Miller of Osceola and J. L. E. Peck and O. H. Montzhument of O'Brien, 1914.
} 
secular historian so far discovered credits J. M. Rust with the first sermon in Lincoln township in 1869 , which is a mistake, since M. D. Collins in 1866 gave in a list from Lincoln class, of eighteen names, contributing fifty cents each to the missionary cause. Rust however may have resurrected an abandoned society. The same author makes amends for his error by saying that Collins carried the gospel message into St. Clair township in 1866.

Of Lyon county we learn that the first known religious service was held by a band of Christian Indians, and in their own language, hence entirely unintelligible to the few white settlers present, of whom the Whitehead family were part. This was in an Indian tepee, at Howell's Grove and the year was the spring of 1870 . While most probably there were Methodist services at least this early, the first of which we have any note was in 1873 , at Rock Rapids, where a class was formed by the Rev. J. B. Starkey, of Sheldon Circuit. ${ }^{36}$

Plymouth county Methodism also furnishes but scanty records, from which we glean that the Rev. Geo. Binks held services in LeMars in 1869, and organized the church there in 1870 ; also that he preached in Cherokee the latter year, reporting only fifty members for both points; however pastors were assigned to both points in 1871, with whom they passed over into the N.W. Iowa Conference regime..$^{37}$

Of Palo Alto county we can only say that there were no Methodist societies, or as far as can be learned, no preaching until 1872, when Col. E. S. Crosby, one of those devout laymen who took their church with them wherever they went, gathered those of like faith with him into both church and Sunday school organization. ${ }^{38}$

Pocahontas history informs us that the Rev. Fred E. Metcalf, county judge and superintendent of schools, labored in his religious capacity of local preacher in and

\footnotetext{
${ }^{58}$ Compendium of History of Lyon County, 1904-05, by Old Settlers Associstion, Chap. 18, p. 114.

${ }^{37}$ Freeman's History of Plymouth County, pp. 274-284. This authority states that the Rev. Mr. Binks formed societies in Seney 1870, and Akron, 1871.

${ }^{3}$ McCarty's History of Palo Alto County, 1910 .
} 
about Rolfe through the years 1862-73; and that the Rev. L. H. Woodworth formed the church in Fonda as part of his Mapleton charge. But, Des Moines Conference records show that Pocahontas was a separate charge in 1869 and 1870 , with D. M. Beams as pastor, having about 100 church members who contributed $\$ 500.00$ for ministerial support, and proportionate amounts for church benevolences. $^{39}$

Of Sioux and Emmet counties the writer has been unable to find any account. The compilers of the only available histories of which were not sufficiently church minded to include such reminiscences in their record of events. That they differed in nature from what has been given of adjacent regions is not at all probable. Of the vast Dakota Territory we have nothing but Conference appointments and statistics for the few years it remained under Des Moines Conference administration, saving for mention some meagre recollections of pioneer clergymen.

The slow development of northwest Iowa, both in population and church life, was due to its physical isolation from older settled regions, to which its only watery artery was the Missouri river, closed to navigation from November to April, and throughout the entire period covered, beset with dangers along its lower course from the agitations accompanying the pro and anti-slavery Kansas contest, and Civil war operations springing from that contest, while beyond Sioux City the stream wound its way through the Indian country, over which brooded the barbaric perils that made Spirit Lake and New Ulm names of horror.

The overland route from eastern Iowa was almost equally forbidding, crossing as it did more than a hundred miles of flat plateau west of the Des Moines river bluffs, largely treeless, strewed by innumerable ponds, and intersected by sluggish streams, that spring thaws and autumn rains swelled into wide spreading lakes, which summer drouths reduced to impassible sloughs and swamps; added to which were the terrors of far raging

${ }^{39}$ Pioneer History of Pocahontas County. p. 262. 
prairie fire in late spring and early fall, and the terrific blizzards of winter. Not till the construction of railroads and extensive drainage projects did this part of the state offer inducement for any but the most adventurous to seek homes there. ${ }^{40}$

These eight years of imperial expansion were transformation years for all western Iowa. The war clouds were banished from all the great river, except in its remote headwaters area. Four trunk railways crossed the state from east to west, and a fifth following close after, all of them putting out feeders north and south, with both main and branch lines adorned with depots and stockyard every few miles, around which arose villages and towns that supplanted the primitive community centers. Most of these speedily faded from sight, including not a few county seats; while those that survived lapsed into insignificance until the surfaced highway epoch gave them a new lease on life.

Promptly recognizing the finger of opportunity the circuit riders extended their elastic bounds to include these centers, to which gravitated the circuit headquarters drawn by the advantages of daily mails, weekly newspapers, better stores and schools. Every new school house dotting the prairies was a challenge to preachers and laymen alike, offering larger accommodations for public services than the pioneer cabins and cottages. A proportionate number of the immigrants pouring into the country were Methodists originally, glad to join up with those already occupying the land; while many of other communions, not finding their own church represented in their chosen locations, added the best features of their own systems to what they found established. ${ }^{41}$

\footnotetext{
${ }^{40}$ For anecdotes of stirring adventures, comic, serious and tragic amid deep mud, swelling flood and Arctic temperatures, see The Battle Field Reviewed, by Landon Taylor: History of North West Iowa Conference, by Bennett Mitchell, and the various county histories mentioned in these footnotes.

41Illustrating the easy blending of denominational lines this writer recalls certain meeting of the estimating committee of a newly created charge on a newly completed branch railway, where all three members of said commitee had been until their removal to this locality members of other denominations. The business of said gathering was to estimate and apportion the pastor's salary, and the outcome of their deliberations left him convinced that the addition of more likeminded with these generous souls would be a distinct asset to any church; it should be added that the spiritual activities of the trio measured fully up to the best Methodist traditions.
} 
As exhibiting this amazing growth we note that in 1871, when the last reports of the entire "imperial domain" appeared in Des Moines Conference minutes, the area covered in 1864 by Fort Dodge and Sioux City Districts with seventeen far flung parishes, reported over fifty such, and a corresponding increase in church and parsonage buildings, with church membership of nearly 7,000 . That similar growth attended the church in the southern and older portion goes without saying, the new modes of travel and transportation giving the one time almost vacant midland prairies an equal footing with their more favored border margins along the waterways. Tracing this development year by year, however appropriate for a 400 page volume, is out of the question for a magazine article, and we must be content with an appraisal of the ministers coming by boundary changes into the enlarged Conference area.

Foremost among these was Phineas T. Biasee, pastor of East Des Moines (Wesley), having had about ten years training in Iowa Conference and so considered competent to administer the new Winterset District, created at the 1864 session, following four years in that capacity by sixteen more in the most prominent churches of the Conference. His progress was marked by flaming revivals everywhere, and business abilities, not always found in the revivalist type of ministers, made him a popular builder and dedicator of churches. Also he possessed a parliamentary talent recognized in 1882 by Bishop Harris, who, called away by the accidental death of his son, appointed Dr. Brasee to preside over the last half of the Conference session. Two years later Dr. Brasee emigrated to California and for some years pursued the same career outlined above; then devoted himself to the evangelistic field, and in time was identified with the Pentecostal movement, from which proceeded what is now known as the Church of the Nazarene, in which he was one of the principal founders, and influential in giv- 
ing that body the fervor and consistency of the Methodism of his earlier years. ${ }^{42}$ Isis.

Equally worthy of notice was Mahlon D. Collins, homesteader of 1856 in Humboldt county, where he opened the first store and was elected first justice of peace in that bailiwick. A Quaker by birthright, he joined the M. E. church, was licensed as a local preacher, employed by presiding elders as supply pastor, admitted on trial by this 1864 Des Moines Conference and continued at Denison where he was already pastor. Endowed with a rare combination of personal charm, soulful eloquence, business acumen, constructive energy and churchly statesmanship, his churches prospered financially and spiritually. Eight years brought him to the headship of Boonesboro District, and four years later to the same position in Des Moines District, then an itinerary among the leading churches of the Conference, until, too late in life for such an adventure he enlisted with Bishop William Taylor as helper-and it was rumored, prospective successor-in African missionary work. Barred by experts in tropical diseases from following this gleam, he became a missionary in the Black Hills, then in Texas where he died. The impact of his personality abides in scores of communities where his name is long forgotten. What an outcome for a country shopkeeper and magistrate on the raw frontier !43

Wm. F. and John Hestwood, ardent pioneers in Upper Iowa, were no less so in Des Moines Conference, where the former held pastorates in Leon, Corydon, Newbern and De Soto, when broken health compelled superannuation. Recovering somewhat, he undertook service on a small rural circuit, and passed away in mid year, leaving a fine example of cheerful hopefulness, despite severe pains, distressing poverty, and the needs of a large family. His brother gave thirty years to the cause of Christ in our borders, achieving the unusual feat of filling two

\footnotetext{
42This appraisal of Dr. Brasee was derived from the Rev. W. S. Hooker, long time close associate and admirer.

${ }^{43}$ For earlier account of Dr. Collins, see History of Humboldt and Kossuth Counties, Union Pub. Co., 1881, p. 792. From 1887 onward personal knowledge and hearsay information supplied details.
} 
pastorates each on the adjacent charges of De Soto and Stuart, both at that time quite prominent churches. He was presiding elder of Atlantic District for a term and ended his active career as financial agent for the Preachers Aid Society.

John M. Dudley, son of a Revolutionary veteran, began his ministry in Pittsburgh Conference in 1842; came to Iowa in 1856, and to Des Moines Conference by realignment of boundaries. About 1872 he moved to a farm near Ames that his children might enjoy the privileges of the newly established state college. He was a good man, influencing for good all whom he contacted. Two of his sons entered the M. E. Ministry, and a grandson followed in their footprints; a daughter married the Rev. Amos E. Griffith, and with him made large contributions to Des.Moines Conference and city Methodism.

John W. Snodgrass, born in 1811 and entering the ministry in 1842, lived to be the oldest Methodist minister on earth. Stationed at Boonesboro in 1863, he completed the church commenced some years previously, and was first of Des Moines Conference preachers to round out the new pastoral term, extended to three years in 1864 . He served faithfully a dozen additional years, then for twenty-five more honored the superannuated relationship with a sunshiny cheerfulness that casts its radiance even unto this present day over some who in youth enjoyed his acquaintance.

Francis M. Slusser, Pennsylvania born, joined Baltimore Conference, emigrated to Iowa in 1856, and was pastor at Saylorville when change of boundaries made him one of us. Civil war service as chaplain of the 33rd Iowa Infantry gave him admission to a soldiers home in Milwaukee after retirement; then in Dayton, Ohio, where he passed away. Having buried his good wife while pastor at Adel, his remains were laid to rest beside hers.

Daniel Lamont came to Iowa in 1859 after four years preaching in Ohio; was presiding elder of Sioux City District in 1862, and stationed at Fort Dodge in the same capacity in 1864-68, the last year a delegate to General 
Conference. Next came a round of appointments taking him in succession to Afton, Dexter, Des Moines Circuit, Perry, Norwalk and Waukee. Superannuating in 1877, he resided in Des Moines for ten years, supplying adjacent charges until he went to the Pacific coast and was colporteur for the American Bible Society three years. His death occurred in 1908. A faithful, earnest, successful preacher of the gospel; a genial, helpful brother, his life was a benediction to every community in which he sojourned. ${ }^{44}$

Of their unnamed colleagues who continued too briefly in Des Moines Conference to claim notice in our limited space, it can be said that they were of like fiber with these, since none other could have endured the toil and privations of those frontier conditions.

Having thus all too briefly evaluated the country and men who planted and served churches therein, we return to the Des Moines Conference session at, Clarinda in August, 1864.

\section{ASSIGNMENTS IN 1864}

It must have been with mixed feelings that the ministers making up the newly named and bounded Conference, took up the task of carrying the gospel to every man, woman and child not cared for by some other evangelical church, in over a quarter of a million square miles of territory. With not a mile of railroad, and but few permanent highways (and they mud roads) and none but makeshift bridges over the countless streams, made travel anything but easy. Their number was fifty-six of whom seven were superannuates; three who had been received on trial the preceding year and seven so admitted at this session made a total of fifty-nine effectives for the gigantic undertaking. There were 126 local preachers on the records, most of whom resided in the older settled portion, and but little available for extension work in the unoccupied re-

\footnotetext{
${ }_{44}$ Except as otherwise noted the foregoing personal sketches are derived from obituarial sources; although the writer's personal acquaintance furnished some items of information.
} 
gions, where only scanty ministerial support could be expected from homesteaders burdened with the task of making raw prairie sod earn living and pay for its improvement besides. These conditions made the $\$ 2,725.00$ granted in aid by the mission board of the denomination, and allocated where most needed, doubly acceptable. Even with this assistance, it was an heroic undertaking that confronted them, and heroes they were who gave themselves to it.

All business disposed of, Bishop Janes addressed the Conference briefly, conducted appropriate devotional services and read out the appointments for 1864-65. The writer has taken the liberty of starring the names of such of this valorous company as he was privileged to know in later years.

Des Moines District-E. H. Winans, Presiding Elder; Des Moines, Fifth Street, S. M. Vernon; Des Moines, Wesley Chapel, J. W. Todd; Des Moines Circuit, Supplied by S. Jones; Rising Sun, W. M. Calfee; Greencastle, J. W. Anderson; Norwalk, S. Haines; Red Rock, John Welch; Newburn, John M. Conrad;* Wheeling, Supplied by B. F. Wright; Palmyra, W. Black; Indianola, Arthur Badley; Indianola Circuit, R. W. Thornburg.

Chariton District-E. M. H. Feming,* Presiding Elder; Chariton, H. B. Heacock; Osceola, A. H. Murphy; Leon, B. Shinn,* R. H. Collins; Mount Ayr, D. B. Clary; Afton, G. J. Nixon;* Hopeville, John M. Baker; New Virginia, James Knotts; Ottawa, F. H. Read; New York, Supplied by W. W. Glanville; LaGrange, John H. Bellamy; Corydon, Geo. P. Bennett.

Council Bluffs District-B. Mitchell, Presiding Elder; Council Bluffs, H. H. O'Neal; * Glenwood, B. W. Coe; Mount Olive, W. F. Laidley; Sydney, D. Thompson;* Clarinda, W. McKendree Cain; Hawleyville, S. Farlow;* Bedford, U. P. Golliday;* Frankfort, J. T. Hughes.*

Winterset District-P. T. Brasee, Presiding Elder; Winterset, C. C. Mabee ;* Adel, M. H. Martin; New Jefferson, Joseph Neigh; Guthrie Center and Panora, S. W. Milligan;* Lewis and Audubon, N. L. Phillips; Harlan, James Lisle; Magnolia, J. W. Adair;* Adair, E. R. Latta; Quincy and Simpson, M. Sheetz; Brooklyn, Wm. Abraham.*

Fort Dodge District-D. Lamont, Presiding Elder; Fort Dodge, W. A. Richards; Border Plains, Supplied by R. S. Hawks; Algona, 
W. S. Dorwin; Webster City, W. F. Hestwood; Nevada, John Hestwood;* Bloomington, John M. Dudley; Boonesboro, J. W. Snodgrass;* Dayton, Supplied by R. S. Clegg; Liberty, J. E. Robins; Alden and Oakland, Supplied by J. H. Carlton; Sac and Calhoun, W. W. Mallory; Spirit Lake, Seymour Snyder.

Sioux City District-J. F. Goolman, Presiding Elder; Sioux City and Woodbury, S. E. Willing; Onawa, To be supplied; Dakota Mission, Supplied by B. C. Golliday; Charles J. Jones, Chaplain 8th Cavalry and member Nevada Quarterly Conference; Smithland and Cherokee, T. D. Adams; Dennison, M. D. Collins.

Of the seven supply pastors noted above, Samuel Jones was a member of Conference, in the newly created supernumerary relation. ${ }^{45}$ W. W. Glanville and R. S. Clegg, local preachers were subsequently admitted to Annual Conference; R. E. Hawks was a local preacher attached to Border Plains Circuit ; B. C. Golliday was a local preacher attached to Sydney Circuit, and most probably a relative of the much more noted Rev. U. P. Golliday; while of B. F. Wright and J. H. Carlton we have found no farther mention. Onawa was without much question hitched onto some adjacent circuit, as the statistical reports for the next year contain no mention of the name.

Since an annual appraisal of progress is out of the question, we merely note that -the fifty-eight charges named above grew to sixty-four in 1865 ; seventy-four in 1866; seventy-seven in 1867; ninety-four in 1868; one hundred and thirteen in 1869; one hundred and twentynine in 1870, and one hundred and fifty-three in 1871. As a concrete example of the rate of growth we mention Dakota Mission, whose forty-one members and one sod chapel in 1864, expanded to eight parishes, with about five hundred membership, one $\$ 10,000.00$ church at Elk Point, and a $\$ 600.00$ parsonage in Vermillion. Next year these eight fields were eleven in number, and in 1880 , Dakota and Black Hills Mission Conferences were struck off from North West Iowa Conference. ${ }^{46}$

\footnotetext{
${ }^{45} \mathrm{~A}$ supernumerary minister, in Methodist parlance, is a member of Conference, who for reasons satisfactory to the body, is not required to travel a charge, but may be employed to supply vacant fields, as in this case, at his own desire.

te See Bennett Mitchell's History of the Northwest Iowa Conference, and the minutes of that body, both to be found in the Iowa Historical collection.
} 
For material and spiritual increases generally in Des Moines Conference, we present the following comparison of statistics for the first and last years that they were published in the annual journals, 1864 and 1871; figures for 1872 from the territory assigned to N. W. Iowa Conference being printed in the minutes of the first session of that body. 1864 membership, 8,435; churches, 45, value $\$ 52,900.00$; parsonages, 25 , value $\$ 16,900.00$; Sunday schools, 189 ; enrollment 10,253 ; benevolence collections, $\$ 2,550.00$; ministerial support, claims, $\$ 25,650.25$; payments, $\$ 23,019.39 ;=89.7$ cents on the dollar. 1871 : membership, 20,911; churches, 108; parsonages, 75; values, inclusive, $\$ 342,500.00$; Sunday schools, 355 , attendants, 23,212 ; approximately $\$ 5,000.00$ paid for missionary and other benevolences; and a ministerial budget of $\$ 96,385.39$ paid $84 \%$ of full.

\section{StRUGGLes OF ChURCH Schools}

The wish for seats of learning on the north and west borders elicited three responses, all in 1867. Undismayed by the dismal fate of Columbus Seminary-midway between them, both Sidney and Glenwood sought and obtained recognition of educational programs. Fremont Collegiate Institute-the Sidney project-had the Rev. J. J. Mendenhall as principal, a brilliant young man, fresh from similar attempts elsewhere, and soon to desert this one, upon receiving a call to a wider opportunity. He rendered good service in several enterprises and died late in the century while acting as editor of the Methodist Review, a religious quarterly of world wide distinction. With his departure, Fremont Institute flickered out. Western Iowa Collegiate Institute, at Glenwood, eked out a nine years existence, setting out with Prof. O. H. Baker as principal, coming from the same position at Indianola; his connection with educational work terminated with his appointment as consul in Australia by President Grant. His daughter, Joanna, was called in later years to the chair of Greek in Simpson College and long honored that professorship by efficient service. The Rev. Peter 
St. Clair took over the Glenwood Institute, passed from there into the pastorate, serving a number of excellent churches, then sad to relate, fell into temptation and was taken red-handed, stuffing the ballot box in an election of delegates to General Conference, was summarily brought to trial, convicted and deposed from the ministry. Passing from our borders, he reappeared after many years, bearing on every feature the signs of exposure to heat, cold, wind and storm; confessed his fault, asked forgiveness and the restoration of his parchments in order to serve more effectively as pastor on a raw frontier; requests most cordially granted, and he took final leave of former associations, cheered on by the fervent "God Speed" of men whose testimony had most contributed to his downfall.

Western Iowa Collegiate Institute struggled on with frequent changes in educators and trustees until engulfed, with its supporters, by the hard times of the 1870's, evoking a Conference order for its sale to pay debts, and a decree. forbidding any attempt at resurrection without Conference consent. Quite possibly the influence of Simpson College alumni may have had something to do in imposing this ban; at least there existed quarter of a century later a resentment that took Glenwood Methodist youth past Indianola to Mount Vernon and Mount Pleasant in pursuit of learning.

The third request for Conference backing came from the northern border, and received the very moderate encouragement of an order that the pastors at Fort Dodge and Algona with the presiding elder of the District investigate the prospects of a proposed seminary at Algona, and report at the next session. Nothing appears relative to this in the 1868 journal, but in 1869 , adoption as a Conference institution was pledged on the fulfillment of certain promises concerning unencumbered grounds, buildings and equipment, with an adequate endowment fund. Progress toward this goal was registered in 1870, and completion achieved in 1871. The next year Algona Seminary became the problem child of North West Iowa 
Conference, in whose journals and Bennett Mitchell's history may be found the story of its life, sufferings and death. Along with these projects Sioux City came up from time to time with educational proposals that never materialized until Morningside College came into being, the record of which belongs not to these pages.

Amidst these abortive adventures Indianola Male and Female Seminary moved slowly forward, changing name to Indianola Seminary, and Des Moines Conference Seminary until 1868, when, under the stimulus of aid from the Centenary offerings of 1866, commemorating the hundredth anniversary of the founding of the church in America, the school was raised to college rank, and rechristened "Simpson Centenary College," honoring at once the event that produced its advancement, and Methodism's greatest bishop, perhaps, whose daughters a number of years back gifted this memorial to their eminent father with certain valuable income producing properties in Pittsburgh. The transpiring of numerous Centennials reduced that portion of the cognomen to an encumbrance requiring tedious explanations, and so was dropped; but the former abides, so intertwined with the life and personnel of Des Moines Conference as to require merely brief notice of its future trials and achievements in the further extension of this narrative.

\section{Lay Delegates Sought Recognition}

The most momentous transaction of these two quadrenniums which Des Moines Conference shared with the M. E. church at large, was the culmination of the sixtyyear contest for the admission of the laity to the high councils of the denomination, treated by this writer at more length elsewhere. ${ }^{47}$

The withdrawal in 1828 of the champions of lay rights to form the Methodist Protestant Church sidetracked the controversy for a generation, only to have it revived in the pre Civil war epoch, when it came up every four years,

"ANNALS of IowA, July, 1942, p. 69, Article, Hail and Farevell, Iowa Conference Methodist Protestant Church. 
and was as regularly rejected. But it developed such increasing strength that a plebescite to ascertain the mind of the laity was ordered and taken in 1862; with adverse results. The voting participated in by Western Iowa Conference, with 1008 eligible lay electors, negatived the reform by 315 majority out of 717 ballots cast. Yet at a second test in 1869 this conference reversed itself, along with the entire denomination, producing the cautious amendment of the discipline permitting a layman's Conference to assemble once in four years, whose sole legal function was to choose two lay delegates from each annual Conference to the ensuing General Conference, where the preponderance of ministerial votes would most certainly prevent any mischief arising from their presence; their minority rights being supposedly protected by the provision for a vote by orders-a majority of both classes necessary to pass any measure-upon demand of either laymen or ministers. Under these careful restrictions there assembled at Sioux City, in September, 1871, at the annual session of Des Moines Conference, seventy-seven laymen, representing just one-half of the pastoral charges in the area.

The Lay Electoral Conference organized by choosing as President Hon. Geo. E. Griffith of Indianola, and Edward B. Heaton, local preacher and farmer from a very obscure rural circuit as secretary; then formally notified the ministerial body of their presence, received from them greetings and an invitation to a joint session at which Hon. C. C. Nourse of Des Moines, and Bishop Ames exchanged greetings and compliments for the two bodies. Respectfully declining to re-enact certain resolutions transmitted from the clerical body, the laymen drafted, discussed and adopted others of their own composition, of which one, a recommendation that the principle of lay representation be broadened to introduce laymen to membership annually in Conference sessions on equal footing with the ministry, waited for its realization for another three score years. Then having elected as their delegates to the highest council of their church, H. C. Sigler of 
Osceola, and Gen. W. H. H. Beadle of Yanktor, Dakota Territory, with G. E. Griffith and C. C. Nourse alternates, the laymen adjourned. Sixteen years subsequently, this writer had his first taste of Methodist politics at a similar gathering, over which presided the only one of this original company present. During these years Des Moines Conference established and operated a Church Extension Society, designed to aid new societies financially unable to provide themselves with churches and parsonages; toward which a modest fund was created, and applied.

Other noteworthy features of the 1871 session were the first appearance of presiding elders reports in the minutes, from thenceforward a regular department of the same and a valuable source of information; the impending division of territory, whereby North West Iowa Conference was struck off by the General Conference of May, 1872 , of which no mention is made in the minutes, although expressions found in those of 1872 indicate that disapproval of such action was expressed, and only acquiesced in as a fact accomplished. Among those received on trial appears the first Simpson alumnus to enter the ministry ; also in a long list elected to local deacon's orders is the name of Brenton H. Badley, first Des Moines Conference contribution to foreign mission fields.

This article would not be complete without some account of the more important accessions to the ranks during these imperial years. Heading a class of seven received on trial in 1865 were two whose impact, direct or indirect, was felt on Conference life and polity for more than half a century, with both of whom this historian became very familiar in his "veal" days, standing somewhat in awe of both; the one he admired and respected; the other admired and liked.

Thomas McKendree Stuart, along with his preacher father and three brothers, two of whom entered the ministry after him, came from West Virginia, in which feudridden region he had served in the Union state cavalry; a teacher by profession, but denied collegiate training by 
war conditions, by intense private study he attained classic culture entitling him to the D. D. Little Rock University in 1888. His commanding presence and voice, logical and accurate ways of thought, with combined pulpit and administrative qualities, early promoted him to leading congregations and while relatively young advanced him to the presiding eldership, in which office he served three terms, two of them on Chariton District, with Corning in between, while a judicial mind and dignified reserve equipped him for frequent participation in the trial of ministerial offenders. Appointed to Elk Point Circuit, Dakota in 1867, he wended thither with his bride, their entire worldly possessions packed in a small trunk and huge valise strapped to the back of a two wheeled sulky.

The route lay across trackless prairies, with ofttimes no human habitation in sight through a whole days travel; they swam rivers, threaded tortuous trails amidst bottomless morasses, arriving at last among a handful of hardy adventurers who had little to offer them but a warm welcome to their cramped sod shanties, and scanty frontier fare. There was not another Methodist preacher between him and the Arctic ocean northward, and Oregon to the west. Searching for both saved and unsaved souls over unlimited spaces and acting as superintendent of schools for Dakota Territory besides, the young preacher laid foundation upon which he was permitted in his old age to visit almost a dozen thriving parishes, it was a two years task of which the most modest of men had good right to be proud. With what now looks to me like unwarranted haste, this good man engaged me as supply pastor when my first prepared sermon was yet to be delivered; signed my license to preach and presented my name for reception on trial; moreover, despite blunders of inexperience, gave me warm encouragement at every step of the way. The outstanding visible monument to his activities is Broadway church, Council Bluffs, erected during his pastorate. His analytical mental processes, and not a little Irish pugnacity enlisted him in frequent 
debates with champions of other creeds, as well as extremists within his own.

Without Dr. Stuart's scholastic complex or sermonic ability, William Thomas Smith passed from a county seat editorial sanctum into the ministry with but one sermon "skeleton" as his stock in trade. Genial, alert, informal, resourceful and adaptable to any situation, with memory for names, faces and family details like a steel trap, he inevitably acquired a wide circle of friends, and though never a great preacher, rose to fill the higher posts in the Conference. His talents for organization and almost uncanny insight into the minds and capacities of men made him presiding elder of four different districts, totalling twenty years in that office, a record unequalled by any of his compeers, whom he likewise excelled in stimulating the liberality of his districts in support of benevolent causes; expanded denominational generosity by initiating the move that set apart Easter as Sunday school missionary day; he sat in five General Conferences and was four years general missionary secretary. Such long official service could not escape the tongue of the critics, one of the harshest of whom remarked "Dr. Smith would send the best preacher in the district into the middle of the street at midnight if he could replace him with a transfer who would raise more missionary and presiding elder money; but I suppose that is all right, as it is his business to secure pastors who can build up their churches the most." His adroit faculty of handling situations peeped out in his reply to an inquiry whether he felt nervous about an approaching Conference presided over by a stranger bishop. "Oh no, these bishops are just men like the rest of us, and can be flattered and reasoned with." Our personal relations were close; he baptized my affianced bride, solemnized our nuptials and christened our first child, and once confided his heartfelt grief over the actions of an unworthy son, craving advice in protecting the family name from the effects of his waywardness. His eldest son became an eminent lay evan- 
gelist and a younger one attained a long and useful record in the pastorate.

1868 brought in on trial Wm. C. Martin, already mentioned, and from the same church, Artemis Brown, hereditary slave owner, and prominent clergyman in Kentucky from which he fled "two jumps ahead" 48 of the wrath of the famed Confederate partisan, John Morgan, who carried a rope on his raids for the special purpose of hanging "that old traitor, Preacher Brown" from the nearest tree, in punishment for freely and loudly proclaimed antisecession sentiments. Escaping north, the fugitive cast in his lot with the M. E. church, first in Indiana, then in our bounds. Imbued with a waggish sardonic wit, ${ }^{49}$ that put him in a class by himself, a few anecdotes car best characterize this unique individual:

Asking in a cabinet meeting for a preacher from some other district to place on a charge, he was promptly offered a man by W. T. Smith, who enlarged unctiously upon the brother's fitness without mentioning his name; evading the offer, Dr. Brown renewed his request later to meet the same offer, with no further information furnished; the meeting over, he buttonholed his colleague on the church lawn; "Tommy Smith, I'd trust you in a minute with every dollar I have in the world, but I wouldn't trust you in a preacher trade across the street in plain sight! I've got to know the name of the man you are trying to poke off on me"; and that preacher trade didn't go through. ${ }^{50}$

Preaching at a basket meeting near Chariton, where as pastor and presiding elder he resided for several years, the congregation was much annoyed by a group of hood-

48Utterance of the Rev. Frank M. Evans, one of Iowa's most famous pulpit orators of the last half of the nineteenth century, and briefly in Des Moines Conference, by transfer, when Dr. Brown's application for admission was under consideration.

${ }^{40}$ Anecdotes of Dr. Brown abounded in Conference lore. Dr. Smith related his confab to the writer; the Rev. W. F. Bartholomew wrote up the passage at arms with Bishop Andrews for the church papers early in this century. One bishop, perhaps Dr. Ames, who was something of a sarcastic wit himself, dubbed him "Artemus Ward," from the famous wisecracking jokesmith and lecturer of the period.

50Basket meetings were outdoor all-day Sunday services, with sermons morning, afternoon and night, and sumptuous dinners and suppers; a relic of the early day camp meetings, and like them, as much social as religious functions. 
lums from town who stood around the outer edges ogling the girls and puffing cigar smoke into the eyes of their mothers. Twice the preacher paused and politely asked the rascals to cease smoking, to which they responded by dropping their weeds to one side only to continue the nuisance in a few minutes; then Artemis Brown blew up! "You young fellows out there, I came from a tobacco country, and I know by the smell of the smoke that those cigars of yours were made from frost bitten leaves. In Kentucky they sell 'em for a dime a hundred, and I hope for the reputation of our town, you will bring a better brand along the next time you come out to cut a dash among the farm girls!" Smokers and smokes faded from the scene rapidly, and the services were resumed, in a somewhat hilarious atmosphere.

Brown, very much against his will, was appointed by Bishop Andrews, then residing in Des Moines, to a church badly disrupted by a sad case of ministerial delinquency; six months passed and the bishop stopped over between trains to compliment Dr. Brown on his successful handling of the situation, ending his laudations with, "I really believe Brother Brown your appointment to this place was providential." With the hacking cough that always put the wise on guard, Artemis Brown replied, "I have always understood the crucifixion was providential, but I never thought it reflected much credit on authorities responsible for it!" Falling seriously ill while pastor of a leading county seat church, the joker came to the next Conference not fully recovered but seeking a place. After careful consideration the bishop and cabinet assigned him to a smaller and easier charge paying a greatly reduced salary to that he had been receiving; then to soften the shock of the demotion before the appointments were read called him in to hear his destination, assuring him that after much prayer this seemed the best place for him. Again the dry cough, and "I'm extremely glad bishop and brethren, that you prayed about it, for if you had not, only the good Lord knows where I would have land- 
ed." Falling ill again, he reluctantly climbed up on the shelf, coming only once more to Conference, and delivered a brief valedictory concluding with, "Most of you brethren have thought that I was too funny, but my long illness has so entirely taken that out of me that I can say with the fellow who came home from a course of treatment for stuttering, 'I am completely c-c-c-ured' !'

1870 brought in by transfer Benjamin F. W. Cozier, a stalwart in body and mind, who also attained the district superintendency three times; with a lower jaw like Winston Churchill's and a full measure of the same self assertiveness, he imposed his personality upon preachers and laity alike, generally, but not always to their mutual profit. The same Conference received on trial, William S. Hooker, English born and bred; trained in business as steward of a great estate, and to the preacher trade as a licentiate on a Wesleyan circuit. Cordial, practical, far seeing yet spiritually minded withal, ten years of labor and such thorough Americanization as to rid him of all but the faintest trace of cockney accent, sufficed to advance him from "Hardscrabble Circuit" to city pulpits and three terms as presiding elder, two on Council Bluffs District and one on Creston. During these last six years the writer by close association on long buggy trips over rough dirt roads, and week end entertainment in farm homes brought to me a full realization of the poet's meaning "The Kingdom of Heaven begins in the love of a man for a MAN." His pulpit appeals, couched in a style peculiar to himself, was to the affections and sensibilities; his contacts with pastors and people warm and brotherly; his counsels in the problems of life were the quintessence of common sense; and sore trials by family afflictions never soured the milk of human kindness in his great heart. Around his portrait in a cherished scrap book is pencilled Antony's tribute to Brutus: "This was the noblest Roman of them all!"

These six, Reverends Collins, Stuart, Smith, Martin, Cozier and Hooker, by the close association of overlap- 
ping district superintendencies, so reacted upon each other in their judgments of men and measures as to almost completely dominate Conference life and personnel for well nigh quarter of a century, during which period bishops rotated in presidency annually, oft times arriving at the seat of Conference at the hour of opening the session, leaving them extremely dependent upon the cabinet for essential information to wise administration. It is not strange therefore that this group was credited with "making" prominent ministerial careers possible for blossoming theologues who won favorable notice and were advanced more rapidly than some others, perhaps as competent, who lacking like favor lingered in minor positions indefinitely. Some of these latter, by transferring to other conferences obtained preferment denied them here. Certain it is that this sextet, so wrought upon each other and the various one term presiding elders who shared their responsibilities as to make Des Moines Conference what the writer found it midway of this epoch of the "continuing cabinet." 51

Interspersed with the above were several others received during the years now under consideration. The Rev. A. J. Andres and Hiram T. Curl, admitted in 1867, attained district headship, the former 1876-1880, and succeeded by the latter 1880-1884 on Boone District. A. J. Andres, lawyer by profession, returned to that pursuit for some years, coming back to the ministry about the turn of the century, giving much earnest labor to some needy fields, passing from us in 1904. At the end of his presiding elder term, Hiram T. Curl went as missionary to Dakota Territory, and was continued in that capacity

\footnotetext{
51Cabinet-The unofficial title of the group meetings of bishop and presiding elders during Conference sessions in which Conference business generally and ministerial assignments in particular are arranged; these consultations were in former times so secret that few preachers knew aught of their destination until the appointments were read out just before final adjournment. Within the writer's period of service this secrecy seldom obtained, and I believe has universally been abandoned. "The Continuing Cabinet" was an epithet applied to the group of presiding elders treated of in the text, along with a few Jater incumbants of the office, who like them passed from district to district with brief or no intervals between terms. The acidity of the phrase suggests its origin with disappointed candidates for the office, but the undesirable features of the practice developed such serious opposition that it was mainly discontinued in Des Moines Conference many years before church law required a fixed interval between terms of district superintendency.
} 
in 1885 . The minutes of 1886 contain no trace of his name, as far as can be discovered, either in the obituary department or as transfer to another Conference; nor have the Armstrong papers yielded any further information, leaving the writer with nothing but faint recollections of a word of commendation of this man by W. S. Hooker, who served with him in the cabinet, and of seeing his rather unusual name in Dakota Conference appointments many years ago.

In 1869 Chas. W. Blodgett and William H. W. Rees came in on trial, each also attaining a presiding eldership for a term, with such mixed results, owing to individual idiosyncracies as to remove them from our ranks into the "special transfer" class soon after their district service ended.

Of other mould than any of the foregoing was William E. Hamilton, admitted in 1867, who after several well served pastorates gravitated into pedagogy, and as professor and president, cast the spell of his gracious, pure spirit over thousands of Simpsonians, turning many to the ministry by the magnetism of his transparent sincerity. His picture graces the already mentioned scrap book, encircled by Tennyson's appreciation of his bosom friend, "He bore without abuse, the grand, old name of Gentleman." And at fourscore and three I am taking up the study of his great book on Moral Science.

Of the rest admitted during those two quadrenniums we give space to only one; the alumnus mentioned before, William Christie Smith, received on trial in 1871; who for sixty years progressed from one minor charge to another, never gaining the advancement allotted many another of less ability, piety and efficiency than this earnest, unassuming, devout, spiritually minded, toilsome preacher ; a revivalist of more than ordinary talent, an excellent organizer of raw circuits, and builder of numerous churches. How many of his converts entered the ministry, how many were reclaimed from depths of unrighteousness by his preaching, probably he himself could not have told. 
Of him and seventy others admitted on trial during the period 1864-1871 their best memorial is, "They rest from their labors and their works do follow them." A very few others of that number, not more in proportion than "by transgression fell" from the original Twelve, we pass over in silence; "Disobedient to the heavenly vision" and unworthy of the trust reposed in them by Christ and His cause, let us "Walk backward with averted gaze, and hide the shame," ${ }^{52}$ leaving their betrayal of self and others to the justice and mercies of "the Judge of all the earth."

A few additional transactions within this period might be mentioned; one was the attempt of Winterset District to entrench its position as such by the purchase or erection of a district parsonage for the presiding elder's residence; however, the substitution of Indianola as district head in 1871 terminated the undertaking and the property was sold and the proceeds distributed amongst the donors. So far as the writer can find or remember, no subsequent attempt of this sort has claimed attention.

In 1870 , at the last session before his decease, the Rev. Sanford Haines presented a resolution proposing the centering of Iowa M. E. educational interests in a state university, to which the various institutions then in operation should serve as feeders. This proposition has been broached at various times since, and as often negatived; the amounts now invested in Methodist colleges, plus the maintenance of Wesley Foundations at the three state institutions of learning are likely to forestall such propositions for all future time.

As the General Conference of May, 1872, as already noted, struck off the northern part of Des Moines Conference to form the North West Iowa Conference, it is only proper to give a summary of what the departing unit took with it by way of assets. The new body held its first session in September 1872 and reported fifty-two pastoral charges, mostly immense circuits of which twelve were left "To be Supplied"; the twenty-three members

52See Whittier's Poems; "Ichabod." 
of conference who responded to roll call were increased to forty by admissions and transfers. There were but seven churches in all their vast territory, six in Iowa and one in Dakota; in which last region there were but four other Protestant churches; total value $\$ 19,100.00$, a rather superior type of structures for that country and era. Thirteen parsonages, twelve of them in Iowa were considered worth $\$ 7,000.00$. Algona Seminary with properties worth, on paper, $\$ 24,000.00$, completed the material possessions; pastors and presiding elder's salaries averaged about $\$ 400.00$; benevolent collections, about $\$ 670.00$; while a church membership of three thousand four hundred and forty-nine, and seventy-seven Sunday schools enrolling 3,850 attendants, represented the spiritual harvests of the twenty years or so elapsed since the meagre beginnings set forth in earlier pages herein.

\section{FIRST STREAMLINER IN IOWA}

"The Zephyr," the Burlington railroad's streamlined, stainless steel train, glided with airplane smoothness over the rails from Osceola, Iowa, into Des Moines Monday for public inspection. The train, on its way from the Pacific coast to the world's fair in Chicago, Ill., was to be on exhibition at the Union station.

In the cab of the train, J. S. Ford, veteran Burlington railroad engineer, talked of his years as a steam locomotive engineer and of his new duties on the Zephyr. "Don't ever let anyone tell you," he smiled, "that just because they have taken steam from many of the trains that the romance of railroading is gone."

Since April 18 the train has traveled more than 14,000 miles. The 600-horsepower diesel motor has averaged on the trip more than two and three-quarter miles for each gallon of crude oil. From Chicago, Ill., to Denver, Col., the train burned $\$ 16.00$ worth of fuel. This is less than it would cost to water the average steam locomotive on the same trip, A. Cotsworth, Jr., passenger traffic manager, said.-Des Moines Tribune, July 9, 1934. 
Copyright of Annals of Iowa is the property of State of Iowa, by \& through the State Historical Society of Iowa and its content may not be copied or emailed to multiple sites or posted to a listserv without the copyright holder's express written permission. However, users may print, download, or email articles for individual use. 